Patent clash
$\begin{aligned} & \text { Inventor of blue } \\ & \text { LEDs sues former } \\ & \text { employer } \\ & p 844\end{aligned}$

\title{
Japan's plans for space merger spark fears for basic research
}

David Cyranoski, Tokyo

Japan is to merge its three major space laboratories to create a single organization responsible for all space-related research and development.

The merger plan is in keeping with Prime Minister Junichiro Koizumi's vision of streamlining government-funded research (see Nature 412, 364; 2001). But it is already concerning some space scientists, who fear that manned space flight and engineeringbased activities will dominate the new organization.

The plan will combine the National Space Development Agency (NASDA) with Japan's main aerospace and space-science laboratories. NASDA is increasingly involved in commercial space applications, such as building and launching communication satellites. The National Aerospace Laboratory of Japan focuses on research areas such as fluid dynamics, whereas the Institute of Space and Astronautical Science (ISAS) conducts space science.

"The merger will bring together divided resources and make it easier for researchers to move freely between projects," says Fujiki Kanji, a senior official at the education ministry, which oversees the three laboratories. Sharing major facilities will make the new body more efficient, adds deputy education minister Takashi Aoyama.

Currently, each laboratory has a different funding basis and administrative standing, which will complicate the merger. Aoyama will chair a committee of laboratory managers and outside experts that will plan the details of the merger before the start of the new fiscal year, next April.

Space commercialization is likely to be a major emphasis for the new organization, Aoyama says. But some researchers worry that basic research could be swallowed up by NASDA programmes such as rocket development and participation in the International Space Station, which account for fourfifths of the combined $¥ 194$ billion (\$US1.6 billion) budget of the three laboratories. "The barriers between our basic research and their more applied research will be broken down, and if money is needed for the larger

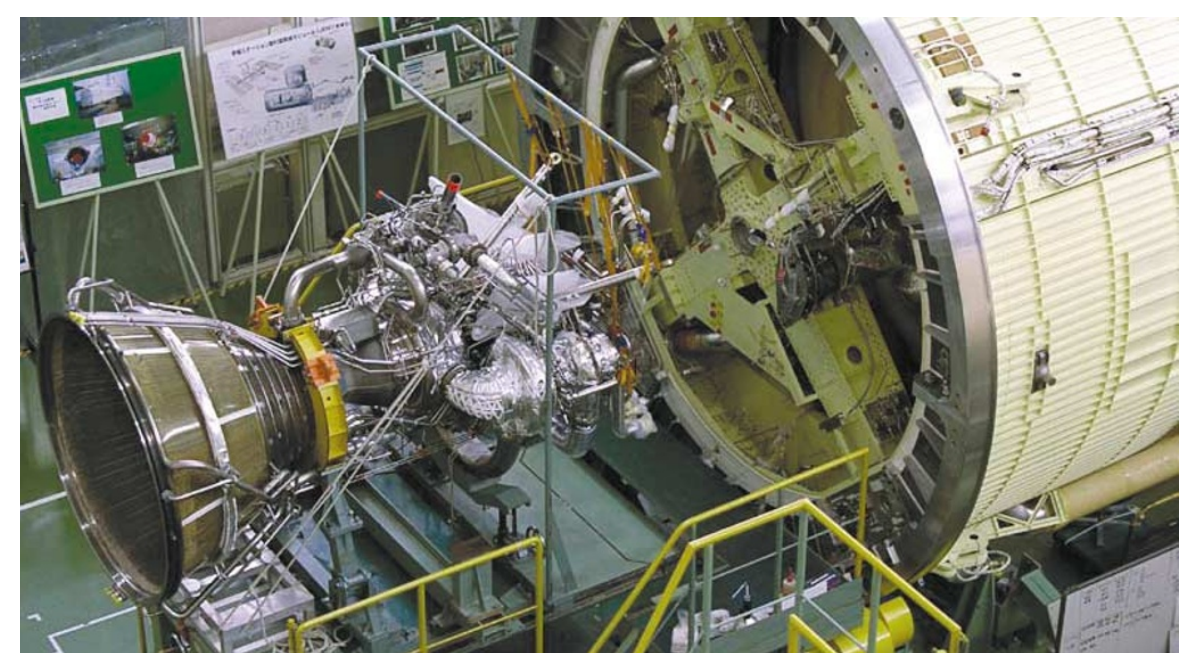

Lofty ambitions: Japan hopes the merger will invigorate space projects, including its H-IIA rocket.

projects, they might take it away from ours," says one ISAS researcher.

Others take a more sanguine view, saying that the change could reinvigorate a field that is facing a crisis of confidence after the failed launch of ISAS' M-V rocket last February, and of two of NASDA's H-II rockets.

\section{http://www.isas.ac.jp/e/index.html}

http://www.nasda.go.jp/index_e.html

http://www.nal.go.jp/Welcome-e.html

\section{Stem-cell list offers sixty-four lines}

\section{Jonathan Knight, San Francisco}

The US government has published a list of the 64 human embryonic stem-cell lines that can be used by publicly funded researchers under the Bush administration's new rules.

Publication of the list, which the National Institutes of Health (NIH) posted on its website on Monday, ended weeks of headscratching among researchers over the large number of stem-cell lines that President George W. Bush claimed existed in his 9 August speech. The list names 10 companies and research labs worldwide that have derived cell lines.

But questions remain about the nature and quality of many of the cell lines, and not all the labs are ready to give the cells out.

The highest concentration of stem-cell lines is in Sweden - 19 at Göteborg University and 5 at the Karolinska Institute in Stockholm. Another 10 cell lines are at two centres in India, with 4 more in Israel.

But CyThera, a San Diego-based company developing stem-cell therapies for degenerative diseases, says it does not know when it will be ready to distribute its nine lines. "We first need to characterize them fully," says its chief operating officer Lutz Giebel.

Audrey Chapman, a science-policy official at the American Association for the Advancement of Science, says the list only begins to address the concerns outlined in an association statement produced on 17 August (see Nature 412, 753-754; 2001).

"The question really is how much more the NIH knows but is not ready to share, or whether they have shared all they know," she says.

www.nih.gov 